\title{
AS ORIGENS DA TERRA JESUÍTICA NA CAPITANIA DO RIO DE JANEIRO E A IMPLANTAÇÃO DO ENGENHO VELHO NO SÉCULO XVII
}

\author{
THE ORIGINS OF THE JESUITS LANDS IN THE \\ CAPTAINCY OF RIO DE JANEIRO AND THE \\ DEPLOYMENT OF ENGENHO VELHO IN THE 17TH \\ CENTURY
}

\author{
Marcia Amantino \\ Universidade Salgado de Oliveira, Rio de Janeiro, Brasil, \\ marciaamantino@gmail.com
}

\begin{abstract}
Resumo. Este artigo relaciona a fundação da cidade do Rio de Janeiro em fins do século XVI com o papel desempenhado pela Companhia de Jesus nesse processo. Em função de sua participação nas lutas de conquista da Guanabara, foi uma das maiores recebedoras de apoio político e financeiro. Em um primeiro momento, buscar-se-á apresentar a conjuntura geopolítica da localidade e o papel desempenhado pelas alianças entre europeus e indígenas para a consolidação da cidade. Em uma segunda fase, será demonstrado como a Companhia de Jesus se estruturou na região, mantendo relações com as autoridades e com os moradores, bem como seus mecanismos de inserção social na vida econômica da capitania por meio da implementação, no século XVII, do engenho Velho e da produção de cana de açúcar.
\end{abstract}

Palavras-chave: Companhia de Jesus; engenho Velho; Rio de Janeiro; cana de açúcar; economia colonial.

Abstract. This article relates the foundation of the Rio de Janeiro city at the end of the 16th century with the role played by the Society of Jesus in this process. Because of its participation in the struggles for conquest of Guanabara, the Order was one of the biggest receivers of political and financial support. In a first moment, will seek to introduce the geopolitical environment of the locality and the role played by alliances between Europeans and indigenous to the consolidation of the city. In a second phase, will be shown as the Society of Jesus structured in the region, maintaining relations with the authorities and with the residents, as well as their mechanisms of social integration in the economic life of the captaincy by implementing, in the 17th century, the engenho Velho and the production of sugar cane.

Key words: Society of Jesus; engenho Velho; Rio de Janeiro; sugar cane; colonial economy.

Artigo recebido: 14 de outubro de 2015. Artigo aceito: 3 de fevereiro de 2016.

Am. Lat. Hist. Econ., sep.-dic., 2016, pp. 7-36 | DOI: 10.18232/alhe.v23i3.666v23i2.707 


\section{INTRODUÇÃO}

$\mathrm{E}$ m 1555 os franceses iniciaram a construção de sua fortaleza na Baia de Guanabara, mas anos antes já navegavam pelas suas águas mantendo negociações com os índios tamoios e negando abertamente o domínio do rei português sobre a região. De acordo com Paulo Knauss de Mendonça (1999), ocupar a baía de Guanabara era um projeto francês que tinha como objetivo maior garantir a liberdade dos mares (mare liberum) e, evidentemente, ia de encontro às expectativas dos interesses ibéricos. Interessava aos comerciantes franceses o acesso ao mercado colonial de especiarias, mas ainda no decorrer deste mesmo século, problemas internos na França, fizeram com que o apoio necessário a esta empreitada fosse questionado, e as disputas entre católicos e protestantes acabaram por se estabelecer também na França Antártica, prejudicando muito os seus interesses comerciais (p. 61).

De qualquer forma, só é possível entender o estabelecimento dos franceses na Baía de Guanabara se atentarmos para as alianças que realizaram com os grupos de índios tamoios. A região considerada Sul da conquista portuguesa acabou dividida entre os grupos indígenas que apoiavam os portugueses e os que estavam ao lado dos franceses. A razão destas alianças eram não apenas os acordos firmados entre europeus e os indígenas, mas também decorrentes de inimizades seculares entre os próprios grupos de índios que viviam na região. As alianças feitas e desfeitas entre os diversos grupos entre si e com portugueses e/ou franceses foram peças essenciais no intricado processo de conquista da Baía de Guanabara.

Os primeiros padres jesuítas que chegaram às terras que formariam a capitania do Rio de Janeiro estavam acompanhando Mem de Sá e aos homens que tinham a incumbência de expulsar os franceses que haviam se estabelecido na região graças àquelas alianças efetivadas com os índios tamoios, inimigos dos portugueses. As relações entre os europeus, quer fossem franceses ou portugueses e diferentes grupos indígenas eram já algum tempo, baseadas em alianças e/ou conflitos, e isso significava, nas terras da conquista, ter com esses índios relações de cordialidade, via existência de aldeamentos ou de guerras e de escravidão para os grupos considerados inimigos.

Os jesuítas tiveram um papel decisivo na criação da cidade do Rio de Janeiro. A situação estabelecida na Baía de Guanabara entre franceses e indígenas era perfeita para os interesses religiosos da Companhia de Jesus. A ordem buscava em sua essência conter o avanço do protestantismo e cristianizar os povos pagãos. Na região, eles encontravam os dois exemplos, omitindo que havia no interior do grupo francês, alguns católicos (Mendonça, 1999, p. 227). Nóbrega, em carta endereçada ao cardeal D. 
Henrique, ao relatar a conquista da fortaleza francesa, afirmava que Mem de Sá havia conseguido expulsar os franceses "todos luteranos". Segundo o religioso, eles "seguiam as heresias da Alemanha principalmente as de Calvino [...] e segundo soube deles mesmos e pelos livros que lhes acharam muitos, vinham a esta terra semear estas heresias pelo gentio" (Mendonça, 1999, p. 226). De acordo com Baeta Neves (1978), a "invasão francesa-protestante foi uma rara conjunção de duas "guerras", de dois tipos de inimigos que então se aliaram -hereges ("huguenotes") e pagãos ("índios", inimigos) - contra a cristandade (portugueses, leigos e religiosos)" (p. 72).

Em 1560, contando com o apoio de índios aldeados pelos jesuítas em São Vicente e no Espírito Santo, os portugueses e grupos numerosos de colonos vindos de outras capitanias, com seus escravos e homens armados, conseguiram destruir a fortaleza francesa. Contudo, isto não significou que tivessem resolvido todo o problema. Na realidade, a questão principal, ou seja, a presença de franceses na região e seus contatos com os tamoios era anterior ao estabelecimento da colônia e perdurou após a sua destruição. Os franceses continuavam afrontando o poder do rei português e colocando o controle sobre a região em perigo constante. Para Rodrigo Ricupero (2009, p. 95), era essencial manter a segurança deste ponto do litoral para garantir a navegação rumo ao Oriente porque em função dos regimes de ventos, as embarcações se afastavam do continente africano e chegavam ao litoral da costa brasileira. Além disso, a presença de estrangeiros colocava em perigo o domínio não só sobre esta área, mas também, receava-se que a partir de pontos específicos deste litoral, os invasores conseguissem controlar as rotas do Rio da Prata, pois, segundo Armelle Enders (2008), "O Rio de Janeiro é a última grande etapa antes do Sul e mesmo do interior do continente, ao qual o rio da Prata dá acesso" (p. 18). Logo, esta era uma área estratégica que precisava ser mantida a qualquer custo.

Para efetivamente se conseguir a ocupação da região era necessária a pacificação dos grupos indígenas, colocando-os em aldeamentos. Dessa forma, eles seriam mantidos disponíveis para o trabalho de particulares ou para as obras públicas. Àqueles que demonstrassem resistências ao projeto colonial, ou seja, ao aldeamento, a catequese, ao trabalho compulsório e a vassalagem ao rei, estaria assegurada a guerra. Aos que escapassem da morte, restaria a escravização.

Os tamoios, apesar de todos os reveses que já haviam sofrido, ainda resistiam reunidos numa espécie de confederação e tentavam impedir ou pelo menos atrapalhavam no que podiam o estabelecimento definitivo dos colonos na cidade do Rio de Janeiro, nas capitanias de São Vicente, Espírito Santo e São Tomé. Atacavam também os aldeamentos jesuíticos e os grupos de índios tupiniquins, aliados dos portugueses. Este tipo situ- 
ação ocorria em diferentes partes da América e no Rio de Janeiro não foi diferente.

Depois de ter destruído a estrutura da França Antártica, Mem de Sá e seus seguidores iniciaram uma campanha de guerra contra as tribos dos tamoios que continuavam a comercializar com os franceses ao longo de toda a costa. Novamente entraram em cena os serviços dos jesuítas. Em abril de 1563, os padres Nóbrega e Anchieta partiram em direção as aldeias dos tamoios em Iperoig, com a missão de tentar um acordo de paz. A ideia era selar um pacto de não agressão e os índios se comprometerem a não mais atacar os aldeamentos jesuíticos. $\mathrm{O}$ grupo tamoio aceitou por que sabia que pouco tempo antes, os tupiniquins, que eram aliados dos portugueses e dos jesuítas, haviam se rebelado contra eles. Assim, o líder dos tamoios percebeu que a aliança com os portugueses seria uma grande oportunidade para guerrear contra seus inimigos e que os novos aliados nada fariam para impedir. A paz selada entre o grupo tamoio de Iperoig e os portugueses facilitou o ataque aos demais por que quebrou a sua unidade. Sistematicamente, os demais grupos de tamoios foram subjugados, escravizados ou dizimados. Nóbrega e Anchieta conseguiram o sucesso nesta empreitada porque souberam jogar com os conflitos e diversidades culturais que marcavam os diferentes grupos envolvidos na questão e eram profundos conhecedores destas tradições.

E a principal razão que os moveu a quererem a paz não foi o medo que tivessem aos Cristãos, aos quais sempre levaram de vencida fazendo-lhe muitos danos, nem necessidade que tivessem de suas coisas, porque os franceses que tratam com eles lhas dão em tanta abundância assim roupas, como ferramentas, arcabuzes e espadas, que as podem os Cristãos comprar a eles, mas o desejo grande que tem de guerrear com seus inimigos Tupis, que até agora foram nossos amigos, e pouco há se levantaram contra nós outros [...] queriam eles agora com o mesmo favor [dos portugueses] ser vencedores e vingar-se bem deles, matando e comendo à sua vontade (Anchieta, 1984, p. 209).

Em 1565, Estácio de Sá, sobrinho de Mem de Sá, chegou à Guanabara com índios temiminós que estavam em aldeamentos jesuíticos no Espírito Santo e que queriam voltar para suas terras, de onde haviam sido expulsos anos antes pelos tamoios (Leite, 1945, vol. vI, p. 233). Os temiminós, liderados por Martim Afonso, nome cristão de Araribóia, viram no apoio aos portugueses uma forma de vingar os reveses impostos pelos seus inimigos tamoios (Leite, 1940, p. 177). Estácio de Sá mandou também buscar em São Vicente os padres Nóbrega e Anchieta. Outros jesuítas que estavam em São Paulo também contribuíram com índios interessados em lutar contra os tamoios. Formava-se assim uma grande tropa disposta a imple- 
mentar definitivamente um núcleo colonizador na Baía de Guanabara. No primeiro de março de 1565, Estácio de Sá desembarcou no sopé do morro Pão de Açúcar e dedicou o acampamento a São Sebastião. Nascia assim a cidade do Rio de Janeiro, com uma função claramente defensiva e para ser uma base de apoio à colonização lusa na região (Bernardes, 1995, pp. 15-20). Apesar deste ato grandioso, para Armelle Enders (2008, pp. 33-36) a fundação da cidade do Rio de Janeiro deu-se em etapas sucessivas com avanços e recuos de franceses, portugueses e grupos indígenas variados.

Em julho deste ano, Estácio de Sá doou duas sesmarias: a primeira, "e a mais vasta" (Enders, 2008, p. 33) para a Companhia de Jesus -"que permanecerá como a maior proprietária de terras da capitania até sua expulsão do Brasil em 1759"- como reconhecimento por todos os serviços prestados à coroa (Cavalcante, 2004, pp. 25, 56-57), e a segunda para a municipalidade que constava do termo e das terras do rossio. Em 1567, os padres inacianos deram início a construção de seu colégio nas terras situadas no alto do Morro do Castelo. O requerimento do padre Gonçalo de Oliveira, que deu origem ao pedido da sesmaria, informava que ele, por ordens de seu superior, o padre Nóbrega, havia seguido Estácio de Sá na expedição que culminou com a fundação da cidade do Rio de Janeiro e que fizera uma pequena "casa Igreja sob a invocação de São Sebastião", com o objetivo de "abrir porta a salvação de tantas almas perdidas como há no gentio desta terra". Continuava afirmando ser necessário, em função desta necessidade e para o bem dos cristãos, estabelecer um colégio na região, mas que, para isto, precisavam de terras. Assim, solicitava que fosse concedida a sesmaria que começava uma légua e meia da cidade nas águas chamadas de Iguaçu e seguia em direção ao interior até encontrar a tapera Inhaúma e do outro lado, uma quadra de terra em direção ao sertão (Livro de Tombo do Colégio de Jesus do Rio de Janeiro, 1968, pp. 58-62).

Em 28 de agosto de 1567, Nóbrega recebeu a confirmação da carta de sesmaria das terras. As justificativas apresentadas pelo religioso para que fosse feita a doação se pautavam na localização geográfica estratégica da cidade, entre as capitanias do Espírito Santo e a de São Vicente e por que "Há muita gentilidade que se pode trazer ao conhecimento de nossa fé com ajuda de nosso Senhor por meio dos da Companhia se aqui residirem e por ser outrossim importante ao fruto dos cristãos portugueses que ora já residem e ao diante se espera residirem nesta cidade" (Livro de Tombo, 1968, p. 34).

Apesar da cidade ter sido fundada, os problemas continuavam. Não havia água potável, o espaço era pouco, os índios continuavam atacando, enfim, a vida estava organizada em um acampamento militar. Até que em 18 de janeiro de 1567, o governador geral Mem de Sá adentrou com uma frota na baía de Guanabara e dois dias depois, dia consagrado a São 
Sebastião, os portugueses conseguiram se apoderar da aldeia de Uruçu-mirim, um dos principais redutos tamoios. Nessa batalha, Estácio de Sá foi ferido por uma flecha no rosto e dias depois acabou morrendo, mas seu tio, conseguiu tempos depois, expulsar os últimos franceses e tamoios das proximidades da cidade.

Alguns anos após esses fatos, foi assim que o jesuíta Francisco Soares (1966) relembrou aquele dia:

No Rio de Janeiro vieram por vezes muitas naus e franceses com tamoios, que é um gentio mui guerreiro, mas sempre os nossos tiveram vitórias; de uma vez, vieram 80 e tantas naus e dos nossos não havia inda mais q' 7. Com a de Martim Afonso, que é um índio cristão mui esforçado [...] os nossos levam tiros de berços, mas permitiu Deus que se pusesse fogo nas câmaras carregadas de pólvora e tudo ardeu para ser mais claro o milagre; pelejando de parte a parte, como os inimigos eram muitos, tinham os nossos já rendidos, e o capitão Estácio de Sá cativo; arremeteu um soldado esforçado por nome Domingos de Braga e disse q' não queria vida sem seu capitão, com tal fúria, q' rendeu a capitânia do inimigo e tirou o seu capitão e todos com ânimo; tão bem se houveram q' os puseram em fugida; diziam depois os cativos q' viam um homem muito esforçado asseteado, q' era São Sebastião, q' assim se chama esta cidade do Rio de Janeiro (p. 3).

\section{AS TERRAS RECEBIDAS PELOS INACIANOS}

Mesmo depois dessa vitória sobre os tamoios e os franceses, a situação da segurança na recém fundada cidade ainda não estava plenamente resolvida. No final do século XVI, a região do entorno da cidade ainda não estava totalmente ocupada, havendo ainda alguns problemas a serem resolvidos com relação aos índios hostis, ${ }^{1}$ e em função disso os jesuítas tiveram sérias dificuldades para efetivamente ocupar a área recebida. Uma das principais justificativas dadas pelos padres era o tamanho elevado das terras contrastando com o número reduzido de religiosos no colégio. Essa situação fez com que, rapidamente, os moradores os acusassem de não fazerem as terras produzir e de não deixar que eles a ocupassem. Começavam, ainda que timidamente, os distúrbios para os padres na cidade. Estes viviam em um constante dilema: de um lado, para garantir a manutenção de seus projetos missionários, necessitavam ter autonomia financeira e essa só seria conseguida na sociedade colonial por meio da aquisição de terras e do controle

${ }^{1}$ Sobre esta situação, ver por exemplo, os relatos feitos pelo padre jesuíta Luiz da Fonseca sobre a guerra movida por Antônio de Salema contra os índios tamoios da região de Cabo Frio no ano de 1575 (França, 2010, pp. 251-288). 
de um número significativo de mão de obra. Assim, os colégios exerciam, além de suas atividades comuns ligadas ao ensino e à religião, as funções de administradores das propriedades.

Os jesuítas, enquanto indivíduos, mantinham o voto de pobreza, mas os colégios, em nome do projeto maior de levar a fé a um número elevado de pessoas em variados recantos, estavam autorizados a gerenciar consideráveis somas de dinheiro e de riquezas. Apesar de saber que não tinham como produzir em todas as suas propriedades, os padres inacianos mantiveram constantes solicitações de pedidos de sesmarias alegando a necessidade de aumentar o espaço ocupado com os índios dos aldeamentos. Além disso, recebiam também terras como doações.

Os inacianos tinham dois grandes problemas com relação as suas terras: deixá-las abandonadas poderia incentivar a invasão por algum colono ou mesmo a destituição legal por parte da coroa; ocupá-las, tornando-as produtivas, ainda era, nos anos finais do século XVI, atividade proibida pelos superiores. Essa situação só sofreu mudanças a partir de 1590, quando o padre geral, Aquaviva, autorizou mediante argumentos variados, o plantio de cana de açúcar nos engenhos da Bahia. ${ }^{2}$

Contudo, mesmo antes da autorização dada pelo por Aquaviva, da maneira que podiam e sem desobedecer aos ditames de seus superiores, os padres do Rio de Janeiro estavam tentando encontrar soluções para as suas posses. Em 19 de janeiro de 1577, o reitor do colégio, o padre Braz Lourenço, permitiu que Gaspar Sardinha, que já era rendeiro, aumentasse as terras para a ereção de um trapiche de açúcar. O rendeiro poderia ficar na propriedade por um prazo de 18 anos. De acordo com Carl Egbert Mello (1996, p. 149) esse seria o segundo engenho de açúcar criado no Rio de Janeiro. Uma das condições do arrendamento era que Sardinha deveria construir o trapiche em dois anos e de cada cem arrobas de açúcar produzido, duas e meia seriam do colégio. Caso não conseguisse estabelecer o trapiche no prazo estipulado deveria pagar "a razão de cruzado por cem braças em quadra". Qualquer melhoria ou plantação feita nas terras acarretaria também o pagamento de mais foros (Livro de Tombo, 1968, pp. 127129). Como a montagem do trapiche exigia muitas terras ele englobaria as parcelas de dois outros lavradores, que se tornariam foreiros do engenho dele. Os jesuítas autorizaram e deram um prazo de dois anos para que ele

\footnotetext{
${ }^{2}$ Os principais argumentos usados pelos que defendiam a liberalização da produção pelos inacianos era que o plantio e a remessa de cana de açúcar promoveriam uma maior autonomia financeira aos colégios; que graças a essa autonomia, os padres poderiam ampliar o número de missões e que também os beneditinos e os carmelitas já estavam plantando o produto em suas terras e logo se tornariam poderosos. Além do que os padres já estavam envolvidos com a rota da seda no Oriente, portanto, poderiam se envolver com a produção de cana de açúcar no Brasil (Alden, 1996, p. 416).
} 
montasse o engenho de açúcar. Em caso de descumprimento, pagaria foro mais elevado e não poderia impedir os demais foreiros de ocuparem as terras. Apesar de não existir registro do que aconteceu sabe-se que em 1579 esse engenho foi vendido a Paulo Dias de Novaes, governador de Angola e nesse momento, pela primeira vez, o nome de Salvador Correa de Sá apareceu como ex-sócio de Gaspar Sardinha no referido trapiche (Livro de Tombo, 1968, pp. 130-131). O colégio passou então o arrendamento a Paulo Dias de Novaes com as mesmas condições anteriores. Em três de janeiro de 1584, o governador de Angola escrevia para sua irmã em Lisboa, informando que seu engenho no Rio de Janeiro já estava produzindo e, segundo lhe diziam, o açúcar era "tão bom como da Ilha da Madeira" (Brasio, 1952, vol. IV, p. 427). Pelo visto, o governador de Angola não havia sido informado sobre a qualidade ruim do açúcar produzido na capitania do Rio de Janeiro. Apesar desta aparente boa notícia, Paulo Novaes teve alguns problemas com sua posse. Seu próprio pai criticava seu interesse nessas terras produtoras de cana de açúcar na América portuguesa. Para ele, os inimigos de seu filho poderiam acusá-lo de dar mais atenção aos seus negócios ligados a agro manufatura da cana de açúcar e do tráfico de negros do que a efetiva colonização de Angola, que, naquele momento, passava por sérias dificuldades (Brasio, 1952, vol. IV, pp. 310-314).

De acordo com Claudia Cristina Alexandre Santiago (2015) não haveria nenhum impedimento nos negócios do governador de Angola no Rio de Janeiro: "A ideia de integração do império poderia ter levado o governador a transpassar a distância e realizar transações na América portuguesa, pois estava negociando em território de domínio lusitano, não ferindo, portanto, qualquer código real. Mas esses negócios não eram bem vistos pelos seus compatriotas e de certo, alguns dos patrocinadores da conquista angolana também não ficaram satisfeitos" (p. 25).

Entretanto, o governador de Angola morreu no ano de 1589 sendo enterrado na capela dos jesuítas da cidade de Massangano, deixando bens para a Companhia de Jesus (Brasio, 1952, vol. IV, pp. 512-513). Desconhece-se se no testamento existiria alguma cláusula de retorno dessas terras para a Companhia, mas em 1600 já não havia mais registro da existência do engenho (Abreu, 2010, pp. 270-271). É interessante perceber como as pontas do império -América portuguesa e África- mantinham relações não apenas comerciais, envolvendo a remessa de produtos e de escravos, mas também a troca de homens que possuíam interesses e negócios nos dois lados do Atlântico.

Em 1602, o padre Pero Rodrigues, que havia sido mandado como visitador da ordem, foi enfático em sua carta ao superior relatando os problemas que o colégio do Rio estava enfrentando com os moradores: "Indo a cidade para diante e crescendo em moradores por razão do comércio de 
Angola e do Rio da Prata, pediram alguns homens essas terras aos padres para as aproveitarem, mas não lhas deram, e chegou a coisa a tanto que o Ouvidor Geral Gaspar de Figueiredo Homem disse publicamente que havia de informar a S.M. como os padres tinham nessa cidade muitas e boas terras, as quais nem podiam aproveitar nem davam a moradores". ${ }^{3}$

Tentando dar uma solução para a questão, o padre ordenou que todos os religiosos dessem explicações a respeito dos benefícios e dos malefícios de se entregar parte das terras aos moradores da cidade para que eles as fizessem produzir. O medo do religioso e de outros era o de que a Companhia de Jesus acabasse perdendo essas terras. Por sua lógica, era melhor aforar e receber com isso uma renda anual do que deixar as terras paradas ou ainda acabar perdendo-as definitivamente. Os argumentos dos padres contrários ao aforamento eram que os bois e os escravos dos novos engenhos causariam danos aos padres; que os seus escravos acabariam tomando o "vinho do mel do engenho", ou seja, a aguardente e se envolveriam em brigas; a água que servia à Quinta (na fazenda de São Cristóvão) ficaria suja para o consumo e que por último, o porto dessa mesma fazenda ficaria devassado. Os argumentos favoráveis explicavam que o aforamento traria rendas para o colégio; os dízimos que os padres recebiam poderiam ser recolhidos nessas produções; aumentando a produção de açúcar mais embarcações chegariam ao porto da cidade e com isso, os preços das mercadorias cairiam, e finalizavam alegando que se eles não dessem essas terras a quem queriam aproveitá-las o rei poderia dá-las a outros ficando a Companhia sem esses bens.

Segundo Serafim Leite, os jesuítas optaram por exercer sobre suas terras tanto o sistema de aforamentos quanto o de arrendamentos de acordo com seus interesses, com o tamanho da terra e a importância do solicitante. No sistema de aforamento, o senhorio do imóvel delegava a outrem todos os direitos de domínio mediante um pagamento anual, conservando para si o domínio direto. Tratava-se de uma situação de caráter perpétuo e transmissível aos herdeiros (Alveal, 2005, p. 287). Já no sistema de arrendamentos a ocupação e o uso eram temporários mediante também o pagamento de uma quantia anual (Secreto, 2005, p. 40). Nos dois casos, a Companhia de Jesus mantinha o domínio real sobre suas terras e as utilizava como uma importante fonte de renda para a manutenção dos seus projetos.

A conclusão de todos os debates foi que o padre Pero Rodrigues, que era favorável ao aforamento das terras, ordenou que se dessem "uma água

\footnotetext{
${ }^{3}$ Informação das águas e terras do Colégio do Rio de Janeiro que dei para fazerem engenhos no ano de 1602. Rio de Janeiro, 30 de junho de 1602. Arquivo Romano Societas Iesus, Brasilia 81. História, 1574-1619, ff. 10-11, citado por Abreu (2010, p. 271).
} 
e terra" a Álvaro Gomes para que ele fizesse um engenho. Depois autorizou que uma terra fosse aforada em caráter perpétuo para Estevão Gomes e outra para Álvaro Fernandes Teixeira erigir um engenho chamado de Nossa Senhora de Guadalupe. Há indícios de que houve uma autorização também em 1615 para que Manoel Dias pudesse erigir seu engenho (Abreu, 2010, vol. I, p. 273), mas parece que só o aforamento de Alvaro Fernandes seguiu em diante (Livro de Tombo, 1968, pp. 81-183).

$\mathrm{O}$ engenho de Nossa Senhora de Guadalupe foi vendido depois a $\mathrm{Du}$ arte de Albuquerque e, entre os anos de 1610 a 1624, esteve nas mãos de Baltazar Borges. Suspeita-se de que é esse engenho, que voltará mais tarde, para o domínio dos jesuítas e se constituirá no engenho Velho (Abreu, 2010, vol. I, p. 273).

Além desses engenhos, os padres arrendaram parcelas menores de terras a lavradores de variados grupos sociais e econômicos. De acordo com Maurício de Almeida Abreu (2010, vol. 1),

$\mathrm{Na}$ antiga sesmaria de Iguaçu, muito mais próxima e controlável, a paz territorial se estabeleceu através do seu retalhamento em pequenos sítios, que foram aforados a terceiros, sobretudo nas áreas que hoje fazem parte dos bairros da Tijuca, São Cristóvão, Benfica e Caju; surgiram assim um sem-número de pequenas propriedades produtoras de cana, de mandioca, de legumes e de frutas, mantendo os padres em São Cristóvão, para seu uso exclusivo, apenas uma antiga quinta, cujo edifício principal existe até hoje (vol. 1, p. 275).

Na parte das terras que ficaram sob a administração direta dos jesuítas eles se dedicaram à criação de gado, mas nesse momento inicial ainda não existia o engenho. As terras eram chamadas apenas de "terras dos jesuítas". Não se sabe exatamente o ano em que os padres iniciaram as atividades laborais nessas terras, mas em 1620 o padre Antônio de Matos informava que o colégio do Rio de Janeiro já administrava três currais (Leite, 1945, p. 67). Provavelmente, os três criatórios de gados eram o engenho Velho, a fazenda da Papucaia e a fazenda de Santa Cruz, que eram as propriedades mais antigas dos inacianos no Rio de Janeiro. Todavia, com o crescimento da cidade e de sua população, parte do gado que era criado no engenho Velho foi transferido para a fazenda de Santa Cruz e alguns anos depois, a fazenda de Campos dos Goitacazes também passou a criar o gado jesuítico (Leite, 1945, pp. 67-68). A partir da saída do gado, as terras do engenho Velho ficaram totalmente disponíveis para a produção de cana de açúcar, legumes, cerais e frutas visando o abastecimento do colégio e das residências, mas também a exportação.

Em algum momento a partir de 1624, quando as terras já não estavam nas mãos do arrendatário Baltazar Borges, os padres começaram a 
se dedicar a produção de cana-de-açúcar, produto muito mais valorizado no mercado externo e, portanto, com maiores capacidades de gerar lucros para o colégio, demonstrando que estavam inseridos nas mesmas lógicas econômicas que regiam os demais produtores da cidade e da capitania. Além dos padres, os foreiros também produziam cana de açúcar e parte dessa produção era entregue aos religiosos como pagamentos dos arrendamentos.

A decisão dos inacianos de iniciarem, efetivamente, o aproveitamento agrário de suas terras, tem relação direta com o contexto econômico da capitania do Rio de Janeiro no século XVII e de suas relações com o império português que, segundo Schwartz, podia ser dividido em dois sub sistemas: o Indico formado por fortalezas, comunidades mercantis e centros administrativos da costa da África e da costa da China; e o sistema Atlântico, formado pelo Brasil e as "feitorias e os portos da África Ocidental e Central e as Ilhas Atlânticas"(Schwartz, 2010, p. 23). Até meados do século XVII era o primeiro subsistema que dominava as relações econômicas e políticas no império luso, mas a partir desse momento, a situação reverteu-se e, o Brasil assumiu uma posição de destaque no cenário do império.

Tal modificação no sistema econômico do império estava ligada a vários fatores, podendo-se destacar como um dos principais, ou pelo menos como impulsionador das mudanças, a perda da autonomia do reino português para a coroa dos Habsburgos em 1580 decorrente do desaparecimento do rei D. Sebastião em Alcácer-Quibir. Portugal acabou herdando os inimigos da Espanha, principalmente os Países Baixos e a Inglaterra. Rapidamente, os constantes ataques promovidos pelos mercadores e pelos corsários das duas regiões levaram a perdas de territórios e mercados lusos no Oriente, aumentando ainda mais a concorrência entre as potências. Isso não significou, contudo, que o Estado português da Índia tenha deixado de ser lucrativo, mas em 1665 tal Estado já estava reduzido à Goa, Damão, Diu, Bassaim, Macau, China e Índia. Em contra-partida, o lado atlântico do império dava sinais de poder propiciar condições mais rentáveis e sem precisar de grandes investimentos por parte do Estado luso.

Os anos iniciais da União Ibérica (1580-1620), foram favoráveis aos interesses econômicos portugueses, aumentando consideravelmente o acesso a prata espanhola por meio do Rio de Janeiro e aos mercados das colônias espanholas consumidores de produtos e escravos (Subrahmanyam, 2007, p. 58). A produção de cana de açúcar no Brasil crescia rapidamente e os preços estavam em alta no mercado europeu. Além disso, a frota espanhola era muito mais forte e protegia o comércio português em várias regiões.

Contudo, nos primeiros anos da década de vinte do século XVII, a situação já se apresentava diferente para os interesses lusos e a recessão não tardou a dar seus sinais. A guerra dos 30 anos, as disputas contra 
os interesses comerciais holandeses e a criação da Companhia das Índias Ocidentais foram golpes bastante sérios nos negócios portugueses. A partir de 1630, Portugal sofreu duros revesses ocasionados pelas invasões de suas conquistas na Africa e na América pelos holandeses, desorganizando tanto a produção de cana de açúcar quanto o fornecimento de mão de obra africana para as plantações.

Apesar de todos esses problemas, em 1630 o Brasil produziu cerca de 22000 toneladas de açúcar, mas os preços estavam tão baixos que os lucros foram diminutos. Os preços só tornariam a subir por volta de 1640, mas nesse momento já havia a concorrência com o açúcar produzido nas Antilhas (Schwartz, 2010, p. 34). O resultado de todo esse cenário econômico desfavorável foi que Portugal entrou numa grande recessão a partir de 1680. Ainda assim, em finais do século XVII, era claro que o Brasil, apesar de suas atribulações, se tornara "a pedra angular da atividade imperial portuguesa” (Schwartz, 2010, p. 34).

Ainda que o século XVII tenha se apresentado como um período de grandes problemas financeiros e políticos para Portugal, o mesmo não pode se afirmado para a capitania do Rio de Janeiro. Pelo contrário, foi nesse momento, de mudanças bruscas nos rumos do império, que a capitania se integrou à economia atlântica. Comparando os números de engenhos em funcionamento que existiam no século XVI e no seguinte, observa-se que, apesar da crise dos preços do açúcar nos mercados externos, os produtores da capitania não deixaram de investir no produto, demonstrando que havia uma significativa margem de autonomia financeira entre Portugal e o mercado local. Para Antônio Carlos Jucá de Sampaio (2014), a "existência de um pujante mercado interno gerava uma forte autonomia local em relação às conjunturas externas, o que nos permite falar de uma conjuntura oposta à do reino de Portugal no mesmo período" (p. 401).

Parte dessa autonomia pode ser pensada em função das facilidades encontradas internamente e que remetem ao "capital social básico" que os colonos precisavam para iniciar suas atividades, ou seja, acesso a terras e o controle sobre a mão de obra indígena. Isso foi conseguido na capitania do Rio de Janeiro ao longo do século XVI, o que fez com que na segunda metade do século XVII, os principais grupos que mantinham resistências mais efetivas já estavam afastados, escravizados ou mortos, restando apenas pequenos focos de indígenas insubmissos (Sampaio, 2003, p. 62).

Além disso, há que se levar em conta também que a conjuntura econômica da capitania a levava a ter relações comerciais legais ou não com a região do rio da Prata, com a África e com a manutenção de um importante mercado interno consumidor e abastecedor de alimentos, tanto para a própria capitania quanto para fora dela (Sampaio, 2003, p. 62). 
Dessa maneira, ao assumir o cargo de reitor do colégio do Rio de Janeiro em 1646, o padre Simão de Vasconcelos relatou para seus superiores em Roma que o mesmo estava muito bem em termos econômicos "porque tinha um engenho de açúcar e currais que podiam render a cada ano mais de 15 mil cruzados". Além disso, como suas dívidas não eram significativas, o colégio poderia "pagar parte das dívidas dos outros da Província". Terminava seu relato informando que "embarcara numa frota mais de 5 mil arrobas de açúcar, que deveriam importar para Lisboa 20 mil cruzados” (citado por Assunção, 2004, p. 175). De acordo com sua informação esse dinheiro seria usado para pagar dívidas que outros colégios tinham em Portugal (Assunção, 2004, p. 175).

Muitos anos depois, ao redigir uma obra inocentando os jesuítas de tudo o que o marquês de Pombal os acusava em termos de negócios escusos, José Caeiro confirmava essa informação de que o colégio de Lisboa servia como uma espécie de centro recebedor e distribuidor de produtos oriundos dos demais colégios da Companhia. Informando que o prelado da Bahia havia ficado responsável por averiguar que tipos de negociatas os jesuítas realizavam na região, o mesmo exigiu que fossem apresentados os livros de receitas e despesas, mas neles não encontrou nada sobre o comércio. O prelado ordenou então, aos reitores e procuradores "por cartas juradas atestassem que nem antes nem então algum deles exercera o dito comércio" (Academia Brasileira de Letras, 1936, p. 41). Os jesuítas assinaram, "Porque realmente o açúcar e outros frutos que das suas fazendas colhiam eram despachados para Lisboa; e de lá depois de pagos os transportes a maior parte se vendia; e com o preço de sua venda se compravam as coisas, que eram precisas e se enviavam para o Brasil, onde se repartiam pelas diversas casas da Companhia e se gastavam nos usos a que se destinavam" (Academia Brasileira de Letras, 1936, p. 41).

$\mathrm{O}$ mesmo controle ocorreu nas demais capitanias e os padres que estavam em Pernambuco, no Rio de Janeiro ou em Goa também assinaram papéis com os mesmos teores (Academia Brasileira de Letras, 1936, p. 41).

A conjuntura interna da capitania se refletia no número de engenhos criados (ver tabela 1). De acordo com Maurício de Abreu (2010), a partir dos últimos anos do século XVI até o final do seguinte, o crescimento dos engenhos foi constante, atingindo o auge na década de 1640. Uma outra conclusão desse pesquisador, foi que houve uma dispersão desigual pelas diferentes áreas da capitania e esta teve ligação direta com as frentes de expansão da população, ou seja, na medida em que grupos indígenas eram conquistados-aldeados ou extintos, levas de colonos entravam pelas áreas estabelecendo engenhos e engenhocas (vol. II, pp. 94-97).

Utilizando os dados fornecidos por Frédéric Mauro (1997) a respeito do crescimento do número de engenhos na capitania do Rio de Janeiro 
TABELA 1. ENGENHOS DE AÇÚCAR EM FUNCIONAMENTO, RIO DE JANEIRO, SÉCULOS XVI E XVII

\begin{tabular}{lc}
\hline Décadas & Engenhos \\
& 3 \\
$1571-1580$ & 3 \\
$1581-1590$ & 5 \\
$1591-1600$ & 13 \\
$1601-1610$ & 23 \\
$1611-1620$ & 35 \\
$1621-1630$ & 53 \\
$1631-1640$ & 106 \\
$1641-1650$ & 113 \\
$1651-1660$ & 116 \\
$1661-1670$ & 125 \\
$1671-1680$ & 132 \\
$1681-1690$ & 136 \\
\hline
\end{tabular}

Fonte: Abreu (2010, vol. II, p. 94).

entre os anos finais do século XV e os anos iniciais do século seguinte, Antônio Carlos Jucá de Sampaio, estima que em "aproximadamente seis décadas o número de engenhos no Rio de Janeiro cresceu mais de 3.500\%" (vol. 1, pp. 254-265). Para Sampaio (2014), os engenhos eram os bens de maior valor naquela sociedade, mas eram também "a absoluta prioridade" em termos de investimento. Não eram apenas bens econômicos. Naquela sociedade, marcada por regras e hierarquias ligadas ao mundo do Antigo Regime, ser senhor de engenho implicava ter prestigio, poder político e acesso a escravos (Sampaio, 2014, p. 387). Assim, em busca desse status social os que eram mercadores investiam grande parte do que arrecadavam no setor agrário, mas visando aumentar os lucros, os senhores de engenho, quando podiam, também investiam no comércio (Sampaio, 2003, p. 76).

Os padres não escaparam dessas ideias e muitos foram os que tiveram terras e tornaram-se senhores delas e de homens. Os jesuítas, embora tivessem sido os mais eficientes e poderosos proprietários não estiveram sozinhos. Mesmo para eles, possuir terras significava compartilhar dos valores daquela sociedade, significava estar totalmente integrado às regras de convivência.

João Fragoso (2007) chamou a atenção para uma característica econômica específica da capitania do Rio de Janeiro. O seu solo produzia um 
açúcar considerado de má qualidade, ou de segunda linha. Ainda assim, sua elite, ou seja, os homens que realizaram a conquista de seu território aos índios e aos franceses, conseguiram alicerçar suas bases econômicas e políticas na grande empresa açucareira. Logo, as regras para o entendimento dessa sociedade não passavam apenas pelo mercado.

¿O que explicaria a manutenção dessa economia, denominada por Fragoso de "esquisita"? Segundo Fragoso (2007), a elite senhorial usava argumentos políticos alegando a importância estratégica da localização da capitania para a segurança do império luso no Atlântico sul e a fragilidade econômica desse mesmo império para fazer uma espécie de blindagem política e econômica para seu açúcar. Com isso, conseguiam manter preços artificiais e se protegiam das flutuações do mercado internacional. "Assim, a nobreza principal da terra conseguia dar base material à sustentação de seu poder. Ao mesmo tempo, ao blindar tal economia, a nobreza realizava, aos olhos dos moradores, a defesa do bem comum, pois daquele açúcar dependiam suas vidas, sendo essa legitimidade lastreada tanto por senhores de moenda não nobres como por lavradores forros" (Fragoso, 2007, p. 100).

Além disso, membros da elite, usavam de seu poder, como foi o caso, por exemplo, de Salvador Correia de Sá e Benevides, governador da capitania, que em 1653 tentou fazer com que fosse aprovada sua solicitação de que pelo menos $10 \%$ da ocupação dos navios que saíssem do porto da cidade, o fossem com seu açúcar, além de um considerável desconto nos fretes (Caetano, 2009, p. 89).

Dauril Alden (1996, p. 428) e outros autores já chamaram a atenção para uma faceta da produção jesuítica: os padres não arriscaram em suas terras nenhuma inovação, quer seja de produtos quer seja de técnicas. Seguiram os rumos das regiões onde estavam estabelecidos. Quando estavam no papel de administradores de seus engenhos se comportaram como qualquer outro colono, ou seja, foram tradicionais e conservadores. Porém, a diferença que existia entre eles e os demais pode ser percebida na capacidade que tinham para realizar grandes obras e projetos, além é claro de sua disciplina. Os jesuítas, ao se decidirem pela produção de cana de açúcar em suas terras, estavam apenas seguindo os rumos econômicos da capitania, pois, "no século XVII o investimento em bens agrários é a absoluta prioridade da sociedade fluminense" (Sampaio, 2003, p. 73). A economia da capitania e os rumos políticos do império fizeram com que os inacianos adotassem claramente uma política de incorporação de terras. Alegando o perigo de que os holandeses invadissem o litoral norte do Rio de Janeiro como haviam feito no Nordeste e justificando que apenas os índios de seus aldeamentos de São Lourenço, São Barnabé e São Pedro do Cabo Frio seriam capazes de defender a região, conseguiram doações de terras no ano de 1630. Nessas terras os padres implementaram posteriormente suas 
fazendas de Campo dos Goitacazes, de Sant'Anna de Macaé e de Campos Novos. Essas unidades produziam cana de açúcar e gado, abastecendo a região e a cidade do Rio de Janeiro. Assim, em meados do século XVII, a Companhia de Jesus já havia montado seu complexo sistema agrário na capitania. Ele era formado por nove engenhos e ou fazendas, por quatro aldeamentos, inúmeras pequenas propriedades e tudo era administrado pelo colégio do Rio de Janeiro. Juntas, estas estruturas significavam para a ordem, o acúmulo de terras e de mão de obra, nativa e negra (Engemann e Amantino, 2013, p. 20).

O engenho Velho, primeira unidade agrária inaciana em terras da capitania do Rio de Janeiro, foi uma espécie de laboratório onde os padres colocaram em prática decisões e administrações que já estavam sendo testadas em suas terras da Bahia há alguns anos e por meio dele, tentavam criar condições financeiras favoráveis aos seus interesses (ver mapa 1). Entretanto, no Rio de Janeiro, assim como na Bahia ou em qualquer outra capitania, os engenhos jesuíticos fugiam ao padrão das demais estruturas agrárias locais.

Os jesuítas também foram agraciados com as legislações que permitiam a escravização de determinados grupos indígenas e, no início da montagem de suas propriedades, tanto no Nordeste, quanto nas capitanias do Sul, utilizaram índios como trabalhadores. Alguns, como os que viviam em seus aldeamentos, eram tidos como índios livres ou como eles mesmos denominavam, forros; outros eram escravos capturados em guerras justas ou adquiridos pelos resgates. As duas categorias trabalhavam em suas terras produzindo bens, coletando produtos ou realizando o escoamento das riquezas rumo às vilas ou cidades mais próximas (Zeron, 2011, p. 165).

A situação chegou a um nível tão significativo, que foi necessário normatizar a prática. Assim, no ano de 1568 a Congregação provincial inaciana autorizou a posse de escravos pela ordem desde que não houvesse outra solução e em 1576 liberou a escravidão indígena pelos padres (Leite, 1945 , p. 349). A partir daí, estava legalizada, pelo menos para os próprios superiores, a utilização dos índios como mão de obra nas fazendas inacianas. Contudo, a utilização desse grupo provocou conflitos, acordos e rompimentos entre os índios e os jesuítas e entre estes e a população colonial. Os padres foram acusados de tentarem impedir a escravização dos índios pelos colonos e ao mesmo tempo, utilizá-los como mão de obra escrava em suas propriedades. Como defesa, alegavam que os índios não eram seus escravos. Eram apenas administrados por eles e que estavam protegidos das agruras de cativeiros injustos. ${ }^{4}$

\footnotetext{
${ }^{4}$ Um exemplo desse conflito foi o movimento de 1640 na cidade do Rio de Janeiro onde os jesuítas quase foram expulsos pela população. Foram socorridos pelo governador Salvador Cor-
} 


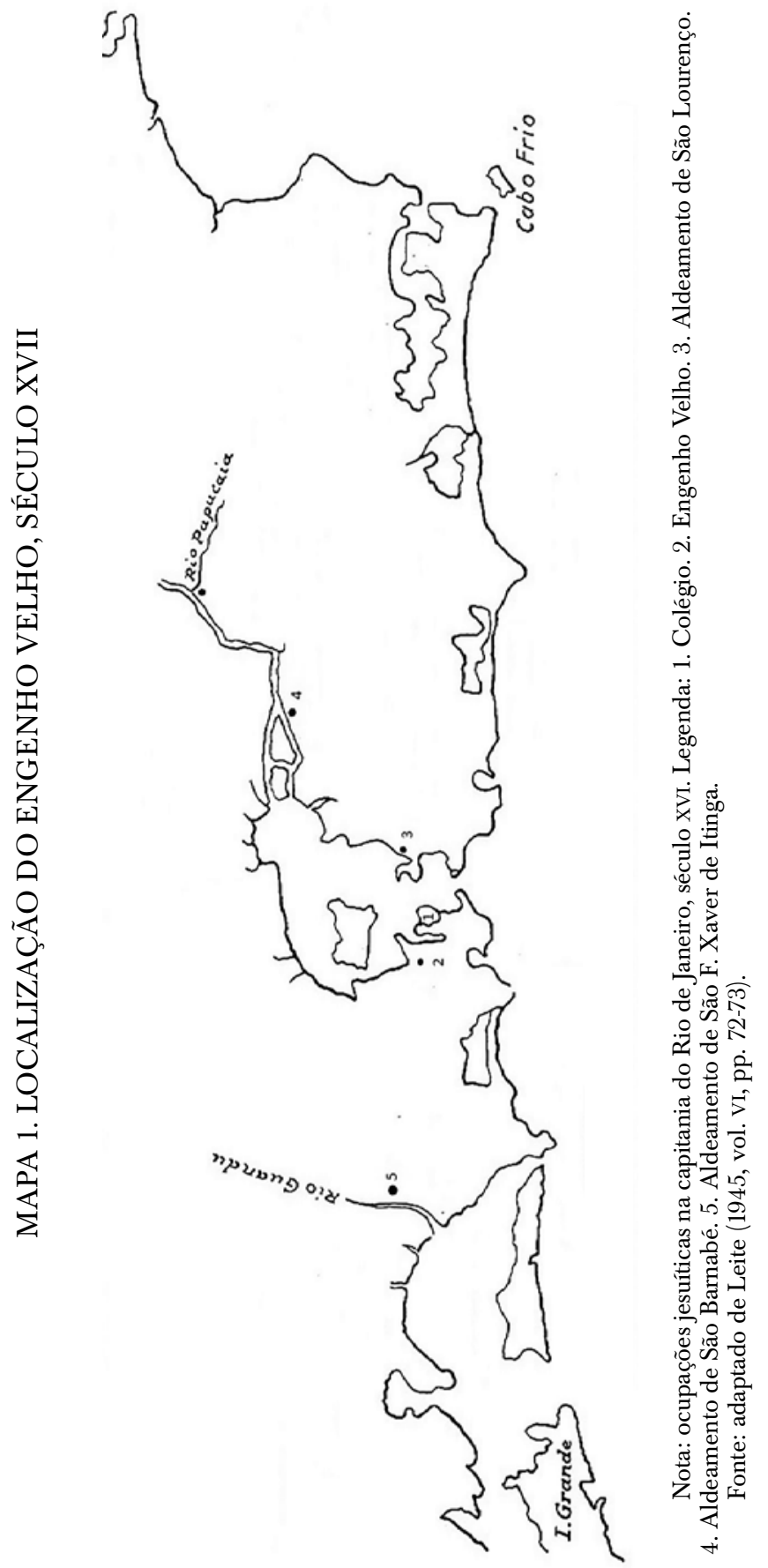


Na capitania do Rio de Janeiro, até os anos finais da primeira metade do século XVII, a mão de obra que abastecia os engenhos e as casas era formada basicamente por índios descidos dos sertões -de maneira legal ou não- ou pelos aprisionados em guerra justa e a utilização deles como mão de obra estava distribuída por praticamente toda a sociedade. Aos poucos, os padres jesuítas foram introduzindo escravos africanos em suas propriedades. Data de 1602, o primeiro relato acerca do convívio entre índios e negros em terras inacianas no Rio de Janeiro. O padre Pero Rodrigues informou que o colégio já possuía "pretos de Guiné" e que estes viviam com os índios nas terras jesuíticas de Iguaçu e ali trabalhavam em roças e serviam nas "obras e em outras cousas". ${ }^{5}$

O engenho Velho, no ano de 1683, foi responsável por $44.6 \%$ do total dos rendimentos do colégio do Rio de Janeiro (Alden, 1996, p. 420). Já no ano de 1694, esse rendimento havia caído para 37.7\%. Provavelmente, não foi a produção de cana de açúcar do engenho que diminuiu, mas a queda originada dos preços do produto no mercado interno e externo (Alden, 1996, p. 426). A solução encontrada pelos padres foi a mesma buscada por outros plantadores: a incorporação de mais terras para aumentar a área plantada, ampliando a oferta de produtos e garantindo assim, a manutenção dos lucros pela quantidade. Em 1707 os padres já tinham em funcionamento o engenho Novo, localizado a algumas léguas do Velho. O motivo da ereção desse novo engenho foi porque a produção de cana de açúcar estava em alta no mercado e as terras que pertenciam ao engenho Velho já estavam desgastadas ou aforadas a terceiros (Leite, 1945, p. 68). Mas essa já é uma outra história.

Da mesma maneira que ampliavam suas terras, os padres também se livravam de partes que já não eram interessantes ou que serviam a algum propósito político. Assim, em algum momento entre o final do século XVII e início do seguinte, os padres arrendaram a Quinta do Rio Comprido que ficava em terras do engenho Velho, ao bispo D. Francisco de São Jerônimo pela quantia anual de 25000 réis, que, segundo Serafim Leite (1945), estaria bastante abaixo do preço de mercado. Talvez os motivos para esse valor baixo fossem o fato do arrematante ser o bispo da cidade e de que, na ausência do governador, ele já havia assumido o cargo, podendo voltar a fazê-lo a qualquer momento. No ano de 1721, o bispo faleceu e então, a quinta do Rio Comprido foi vendida por 13000 cruzados. Com esse dinheiro, os padres da Companhia edificaram uma casa suntuosa na cidade

reia e Benevides e tiveram que aceitar a existência da escravidão dos índios. Ver Vivaldo Coaracy, 1965 , p. 100.

${ }^{5}$ Informação das águas e terras do Colégio do Rio de Janeiro que dei para fazerem engenhos no ano de 1602. Rio de Janeiro, 30 de junho de 1602. Arquivo Romano Societas Iesus, Brasilia 81. História, 1574-1619, ff. 10-11, citado por Abreu, 2010, vol. II, p. 32. 
destinada a ser alugada e o dinheiro do aluguel foi empregado na construção da nova igreja inaciana (Leite, 1945, p. 73).

Os anos iniciais do século XVIII foram caracterizados por uma brusca mudança na cidade do Rio de Janeiro e isso, provavelmente, afetou as atividades da Companhia de Jesus. No final do século anterior, havia sido descoberto o ouro nas Minas Gerais provocando a entrada maciça de africanos e de imigrantes no porto da cidade sendo redistribuídos para as minas. Além disso, os preços na cidade tanto dos produtos quanto dos escravos subiram muito e vários foram os senhores que se desfizeram de seus escravos vendendo-os a peso de ouro para a região mineradora. Outros, abandonaram tudo e se embrenharam pelos sertões em busca de possibilidades de enriquecimentos. De qualquer forma, a cidade cresceu rapidamente impulsionada pela riqueza produzida nas minas.

Apesar de todas as benesses produzidas pelo ouro, a Companhia de Jesus ficou quase à margem do eldorado das Minas Gerais. Ela, bem como todas as outras ordens religiosas, foi proibida de permanecer no território minerador. Assim, as únicas formas legais de participar da riqueza gerada pelo grande crescimento provocado pelo ouro eram por meio das doações que recebia dos seus fiéis, pelas compras de produtos de ouro ou aproveitando as necessidades de consumo que a sociedade mineradora que crescia a cada dia apresentava com relação a alimentos. Havia ainda a possibilidade de conseguirem ouro por meios ilegais, pelos descaminhos. Os padres se dedicaram então a todas essas atividades.

A partir do início do século XVIII, algumas informações relativas ao engenho Velho aparecem misturadas com a do engenho Novo, demonstrando que havia uma possível ligação entre eles. Em termos geográficos isso era totalmente possível. As terras onde foram erigidas o engenho Novo eram contínuas às do engenho Velho. $\mathrm{O}$ "Novo" só recebeu esse nome (dado pela população), para marcar sua oposição ao mais antigo. De acordo com Serafim Leite (1945), o engenho Novo foi erigido porque as terras do Velho já estavam cansadas e não estavam produzindo a contento. Os padres estariam migrando a produção para novas terras no início do século XVIII (Leite, 1945, p. 73). Seja como for, a junção dos dados dos dois engenhos dificulta sobremaneira a análise do engenho Velho como uma unidade agrária, mas por outro lado, permite que se entenda os dois engenhos como uma estrutura produtiva complexa (ver tabela 2).

Como as fazendas e engenhos jesuíticos eram complementares uns em relação aos outros, e todos eles produziam a fim de gerar recursos para manter as atividades do colégio -missionárias, educacionais e outras-é importante analisá-los inserindo-os no contexto maior da economia inaciana local. Isso permite perceber que apesar da expressiva queda na produção de caixas de açúcar do engenho Velho e no Novo no ano de 1740, o 


\section{TABELA 2. PRODUÇÃO DE AÇÚCAR NO ENGENHO VELHO E NO NOVO, SÉCULO XVIII}

\begin{tabular}{llcc}
\hline Ano & Engenho & Caixas de açúcar & Quilogramas \\
1706 & Velho e Novo & 160 & 84000 \\
1730 & Velho e Novo & 160 & 84000 \\
1740 & Velho e Novo & 100 & 52500 \\
1757 & Velho & 40 & 21000 \\
\hline
\end{tabular}

Fontes: Alden (1996, p. 424) e Leite (1945, p. 67).

colégio do Rio de Janeiro não teve prejuízo porque a produção da fazenda de Campos dos Goitacazes, que naquela década já possuía 500 escravos, compensou com uma significativa produção de cana-de-açúcar. Em algum momento anterior, os padres já haviam percebido, quem sabe, uma possível exaustão do solo, uma diminuição da área cultivada em virtude dos muitos arrendatários nos dois engenhos mais próximos à cidade e trataram de deslocar parte da produção de cana-de açúcar para a região norte da capitania, seguindo os rumos tomados por muitos colonos. Dessa maneira, o colégio arrecadou em 1743 uma receita de $48 \$ 652$ mil réis e teve uma despesa de $27 \$ 107$ mil réis. Na realidade, foi o melhor ano econômico da Companhia de Jesus no Rio de Janeiro e com relação aos escravos que trabalhavam em suas propriedades naquele momento, seu reitor, o padre Emanuel de Siqueira, informou como estavam distribuídos os 2337 cati$\operatorname{vos}^{6}$ (ver tabela 3 ).

Onze anos depois, o reitor Joannes Honorato demonstrava que a ordem possuía, na capitania, 2616 cativos e que a fazenda de Campos dos Goitacazes já tinha atingido 820 cativos, enquanto que na fazenda de Santa Cruz havia ocorrido uma diminuição de dez indivíduos. Naquele momento, Santa Cruz possuía 740 cativos; o engenho Novo contava com 148 escravos; o Velho, com 200; a fazenda de São Cristóvão, com 235; a de Macaé havia aumentado seus escravos e passado para 60; a de Papucaia tinha 223, e Campos Novos tinha 190 pessoas. $^{7}$

Os dados constantes destes dois relatórios, enviados pelos reitores sobre a população escrava dos jesuítas nestes momentos, permitem a identificação de que houve uma tendência à diminuição do número de cativos nas fazendas mais próximas à cidade do Rio de Janeiro, enquanto as loca-

\footnotetext{
${ }^{6}$ Catálogos breves e trienais, 1737-1757 Br. 6/II. Arquivo Romano Societas Iesus.

${ }^{7}$ Catálogos breves e trienais, 1737-1757 Br. 6/II. Arquivo Romano Societas Iesus.
} 


\section{TABELA 3. DISTRIBUIÇÃO DOS ESCRAVOS DOS JESUÍTAS PELAS PROPRIEDADES NO ANO DE 1743}

Propriedade

Campos dos Goitacazes

Campos Novos

Papucaia

Macaé

São Cristóvão

Engenho Velho

Engenho Novo

Santa Cruz

Total
Número de escravos

500

163

225

033

250

216

200

750

2337

Fonte: Catálogos breves e trienais, 1737-1757 Br. 6/II. Arquivo Romano Societas Iesus.

lizadas nos Campos de Goitacazes (a fazenda de mesmo nome, a de Macaé e a de Campos Novos), todas recebidas em sesmarias em 1630, vivenciaram um aumento em suas propriedades, ou seja, áreas de exploração econômica mais jovens. No intervalo de onze anos que separa a informação dada pelo reitor padre Emanuel de Siqueira da outra fornecida pelo jesuíta Joannes Honorato, houve um crescimento demográfico apenas na fazenda de Campos Novos e em Macaé (27 cativos em cada uma) e em Campos dos Goitacazes, com um significativo aumento de 320 pessoas, mostrando um crescimento de aproximadamente 29 pessoas por ano. Enquanto isto, em todas as outras fazendas ou engenhos ocorreram maiores ou menores diminuições no número de cativos. Em onze anos, os jesuítas perderam nestas propriedades em torno de 95 cativos, o que dá uma média de 8.6 escravos por ano. Podem ter morrido, fugido, terem sido vendidos ou ainda, remanejados para as outras fazendas que tiveram sua população aumentada. Por enquanto, não há como sabermos.

Estes dois conjuntos de relatórios fazem parte de documentos produzidos pelos próprios padres e enviados aos seus superiores em Roma como forma de controle administrativo pela ordem. Todavia, quando inserimos um outro conjunto documental, também de caráter quantitativo, mas produzida pelas autoridades a partir da ordem de expulsão dos padres de 1759 , esta informação sobre o declínio no número de escravos nas propriedades jesuíticas altera-se substancialmente. Por meio desta documentação, não é possível perceber nenhuma diminuição no quantitativo dos escravos que pertenciam aos jesuítas. Pelo contrário, com exceção das propriedades 
para as quais ainda não foram localizados seus inventários, para o próprio colégio e para a fazenda de São Francisco Xavier que só possuímos os dados do ano de 1759, percebe-se que, comparando os três anos, houve em 1759 um acentuado aumento na população escrava declarada pelos inventariantes $^{8}$ (ver tabela 4 ).

Este incremento na população escrava declarada nos inventários de sequestro dos bens jesuíticos de 1759 pode significar, no mínimo, duas questões: poderia haver interesse por parte das autoridades em aumentar o número total de escravos que a ordem possuía; os padres, ao realizarem seus inventários, sabiam quem eram os seus escravos e quem eram as pessoas livres que coabitavam na fazenda e só registravam as primeiras. Já as autoridades, por não terem este conhecimento, registraram todos os que encontraram, aumentando assim, o numerário.

Esse conjunto de fontes de rendas, gerava à ordem um significativo poder político e econômico que sempre foi questionado pela população colonial, mas à medida em que avançava o século XVIII e a crise se abatia sobre a sociedade portuguesa e sobre seu império, os rumos políticos mudaram e a Companhia de Jesus foi uma das instituições que mais sofreu com a guinada política efetuada por D. José I e seu poderoso primeiro ministro, Sebastião José de Carvalho e Melo, culminando com a ordem de expulsão da ordem em 1759.

Para obedecer ao que determinava a ordem de expulsão, cada autoridade colonial precisou enviar desembargadores para todas as propriedades inacianas. A ordem real determinava que tudo o que fosse encontrado deveria ser inventariado, descrito, e receber um valor para que depois pudesse ser leiloado ou vendido (Amantino, 2009, pp. 169-192). Para realizar essa tarefa, os desembargadores deveriam contar com a ajuda de homens práticos locais para definirem os valores de cada item. Por meio desta documentação pode-se conhecer um pouco mais a estrutura física do engenho Velho em meados do século XVIII. ${ }^{9}$

Os inventariantes descreveram o engenho Velho como sendo uma propriedade produtiva, que estava ainda moendo o açúcar e que tinha todas as oficinas e apetrechos necessários para sua produção. Tratava-se de um engenho real, pois "moe com roda movida com a água". Além de inúmeras peças de cobre ligadas à produção de açúcar, os jesuítas possuíam no engenho Velho alguns espaços especializados de produção, como por exemplo, a casa de encaixe onde o açúcar já pronto era colo-

${ }^{8}$ Arquivo Nacional Torre do Tombo, Libsoa, Portugal. Catálogo Desembargo do Paço, Repartição da Corte, Extremadura e Ilhas. 1759-1760-maço 2038, cx. 1978. Auto de inventário do engenho Velho, 1759; Arquivo do Ministério da Fazenda, Rio de Janeiro, Brasil. Códice 81.20.16. Auto de inventário do engenho Velho.

${ }_{9}^{9}$ Auto de inventário do engenho Velho. Arquivo Nacional Torre do Tombo. 
Am. Lat. Hist. Econ., año 23, núm. 3, septiembre-diciembre, 2016, pp. 7-36

TABELA 4. ESCRAVOS DOS JESUÍTAS DISTRIBUÍDOS POR FAZENDAS E OU ENGENHOS, RIO DE JANEIRO, SÉCULO XVIII

\begin{tabular}{lrrr}
\hline Propriedade & 1743 & 1757 & 1759 \\
Colégio & - & - & 41 \\
Campos dos Goitacazes & 500 & 820 & - \\
Papucaia & 225 & 223 & 317 \\
Campos Novos & 163 & 190 & 190 \\
Engenho Novo & 200 & 148 & 319 \\
Engenho Velho & 216 & 200 & 283 \\
São Cristóvão & 250 & 235 & 329 \\
Santana de Macaé & 33 & 60 & - \\
Santa Cruz & 750 & 640 & 1016 \\
São Francisco Xavier & - & - & 54 \\
Total & 2337 & 2516 & 2549 \\
\hline
\end{tabular}

Fontes: Catálogos breves e trienais, 1737-1757, em Arquivo Jesuítico; Catálogo Desembargo do Paço, Repartição da Corte, Estremadura e Ilhas. 1759-1760, em Arquivo Nacional Torre do Tombo; Autos de inventários e sequestros de várias fazendas, em Arquivo do Ministério da Fazenda.

cado em caixas com determinadas quantidades de arrobas e de lá seguia viagem para o porto ou para o mercado local. Pela descrição das caixas encontradas, pode-se perceber que o encaixotamento do açúcar estava sendo realizado quando as autoridades chegaram. Foram listadas várias caixas de diferentes tamanhos: algumas totalmente cheias de açúcar branco ou do mascavado e outras faltando uma ou duas arrobas para terminar de encher. Mas a casa de encaixe dos jesuítas do engenho Velho permite também comprovar que o seu moinho era utilizado por colonos. Foram encontradas três caixas que pertenciam ao lavrador Manoel de Araújo e uma outra que era pertencente ao dízimo. As caixas do lavrador foram entregues a ele, mas a que pertencia ao dízimo entraram no inventário. ${ }^{10}$

Quando o inventariante passou a descrever a casa de purgar, forneceu mais uma informação sobre a complexa produção de açúcar no engenho. O lavrador Manoel de Araújo, que possuía as três caixas de açúcar, era um meador do engenho e foram identificadas nesse espaço de purgar 21 formas de sua propriedade. Além dessas formas foram identificadas mais sete que pertenciam a um outro meador, o lavrador Francisco de Tal. Parece que as 250 outras formas eram do próprio engenho. Além das formas, a

${ }^{10}$ Auto de inventário do engenho Velho. Arquivo Nacional Torre do Tombo. 
casa de purgar contava ainda com "uma caldeira de cobre em que se purga o mel; um coxo de pau em que se lança o mel; vinte e três toldos de estopa e capa de farda; oito carros capazes de serviço, um dos quais é chapeado; dois carros mais quebrados e velhos; quatro rodas velhas de carro; um carrinho pequeno chapeado". ${ }^{11}$

$\mathrm{Na}$ casa de aguardente foram encontrados quatro alambiques de cobre, quatro tinas, 18 pipas vazias, dois coxos de colocar a cachaça, uma pipa cheia de cachaça, dois barris de carregar água, um funil de pau e mais uma tina pequena. Por esse material, percebe-se que, assim como as demais propriedades da capitania, o engenho Velho também se dedicava a produção da aguardente. $\mathrm{O}$ que infelizmente não é possível inferir é a quantidade produzida e nem o que era feito com o produto. ${ }^{12}$

Apesar da propriedade ser um engenho de açúcar, havia outras produções econômicas e de subsistência nele e isso pode ser percebido no inventário. Depois de enumerar as ferramentas de carpintaria, os inventariantes passaram a descrever a casa da farinha. Foram muito sucintos na descrição. Além da casa, informaram apenas que constavam mais "três fornos de cobre, duas rodas, uma de moer com água e outra de mão, dois coxos de receber a massa". ${ }^{13}$

Uma outra exploração econômica listada pelos inventariantes do engenho Velho foi a atividade criatória de animais. Tudo indica que os administradores do engenho não abandonaram completamente a vocação inicial da propriedade que foi ligada a criação de gado no início do século XVII (ver tabela 5).

A criação de animais sempre foi uma preocupação para a Companhia de Jesus e fonte de rendas para seus colégios. Em Pernambuco, na Bahia no Espírito Santo, em São Paulo e no Rio de Janeiro, o gado bovino sempre representou a imensa maioria do rebanho inaciano. Além desses animais servirem como alimentos para a população das cidades próximas aos seus centros produtores, eram utilizados também em ocasiões especiais ou de doenças para alimentar os escravos da ordem. Serviam também como força motriz nos engenhos de açúcar ou de farinha, puxando os carros de bois e as carroças. Uma outra utilidade financeira era a exportação dos couros. Embora contribuindo pouco com a economia do colégio do Rio de Janeiro, a prática de exportação dos couros para Lisboa esteve sempre presente. Em 1738, o colégio do Rio arrecadou 19800 escudos romanos e a venda de couros representou apenas $2 \%$ de sua receita. No ano de 1743 , essa proporção subiu para $2.8 \%$, demonstrando que a venda do couro não

\footnotetext{
${ }^{11}$ Auto de inventário do engenho Velho. Arquivo Nacional Torre do Tombo.

${ }_{12}$ Auto de inventário do engenho Velho. Arquivo Nacional Torre do Tombo.

${ }^{13}$ Auto de inventário do engenho Velho. Arquivo Nacional Torre do Tombo.
} 
Am. Lat. Hist. Econ., año 23, núm. 3, septiembre-diciembre, 2016, pp. 7-36

TABELA 5. ANIMAIS DO ENGENHO VELHO 1759

\begin{tabular}{lccr}
\hline Gado e cavalgadura & Quantidade & Valor unitário (réis) & Valor total (réis) \\
Bois de serviço do engenho & 138 & 8000 & 1104000 \\
Vacas & 36 & 6400 & 230400 \\
Vacas com crias & 09 & 7200 & 64800 \\
Vitelas e garrotinhos & 24 & 3200 & 76800 \\
Cavalo lazão & 1 & 20000 & 20000 \\
Cavalo lazão & 1 & 8000 & 8000 \\
Porcos & 4 & 2500 & 10000 \\
Total & 213 & 55300 & 1506000 \\
\hline
\end{tabular}

Fonte: Auto de inventário do engenho Velho. Arquivo Nacional Torre do Tombo.

era uma prioridade do colégio para angariar fundos. Uma outra possibilidade para essa participação tão diminuta dos couros na economia jesuítica fluminense pode ser inferida na importância que a exportação do couro tinha na região de Buenos Aires (Grandin, 2004, p. 120), dificultando, ou praticamente impedindo, a concorrência dos produtores do Rio de Janeiro. Entretanto, havia ainda uma outra utilidade para o couro que era o enrolamento do tabaco. Alencastro (2000, p. 341) aponta que $15 \%$ do preço do rolo do fumo embarcado para o exterior correspondia, no final do século XVII, ao preço do couro que o embalava. Talvez o couro produzido nas dependências jesuíticas fosse aproveitado para o enrolamento do tabaco e não para exportação simples.

Analisando todo o rebanho que estava diretamente sob a administração do colégio do Rio de Janeiro ao longo do século XVIII, pode-se perceber claramente que, apesar de algumas flutuações no número de cabeças, houve a manutenção de uma expressiva quantidade de animais na capitania (ver tabela 6).

Infelizmente, não há indicações financeiras sobre o significado desse rebanho para a economia do colégio para todo o século XVIII. O que há é a informação fornecida a esse respeito pelo padre reitor, João Honorato, apenas para os momentos finais dos inacianos na América. Segundo dados enviados por ele aos superiores em Roma, o colégio, o ano de 1757, teve uma receita de 23603 escudos romanos. Parte dessa receita foi obtida graças a venda do gado (7 274 escudos romanos) representando cerca de $30.8 \%$ do total. Outra importante fonte de renda foi o açúcar que rendeu 8000 escudos romanos (33.9\%). O restante dos rendimentos estava diluído entre doações reais, aluguéis de casas, arrendamentos das terras, da venda 
TABELA 6. REBANHO DA COMPANHIA DE JESUS NA CAPITANIA DO RIO DE JANEIRO, SÉCULO XVIII

\begin{tabular}{lrrrr}
\hline Años & Bovinos & Equinos & Ovinos & Total \\
1701 & & & & \\
1707 & 20000 & 1800 & 1000 & 22800 \\
1722 & 17780 & 2864 & - & 20644 \\
1725 & 25133 & - & - & - \\
1732 & 15000 & 5500 & 5600 & 30733 \\
1736 & 15000 & 5000 & - & 20500 \\
1738 & 23836 & 4443 & - & 20000 \\
1743 & 35378 & 5158 & 532 & 28478 \\
1757 & 29141 & 5780 & 92 & 35013 \\
\hline
\end{tabular}

Fonte: Catálogos breves e trienais, 1737-1757. Arquivo Jesuítico.

de remédios e dos "esforços dos procuradores para o colégio". ${ }^{14} \mathrm{Ou}$ seja, tanto o açúcar quanto o rebanho eram as principais atividades econômicas dos inacianos na capitania do Rio de Janeiro. Contudo, é importante frisar que os maiores rebanhos e, portanto, os que realmente faziam diferença na hora de angariar fundos, estavam nas fazendas de Santa Cruz e na de Campos dos Goitacazes. O gado que foi encontrado no engenho Velho era praticamente residual e de trabalho.

A nos guiarmos pelos objetos descritos na casa onde os padres da Companhia de Jesus habitavam no engenho Velho, poder-se-ia afirmar que eles viviam com bastante simplicidade, embora tivessem o necessário para a vida aprendida nos moldes europeus. Na lista apresentada há descrição de toalhas de banho, de mesa, guardanapos, roupas de cama, travesseiros, colchões, pratos, talheres, tigelas, lampião, bancos, etc. Todavia, parte de tudo o que foi descrito aparece como "velho" ou "muito velho". Praticamente não há nenhum item que possa ser descrito como possuindo algum tipo de valor a não ser dois pratos de Veneza e dez do Porto. O restante do chamado "traste" da casa é de uso cotidiano, básico e sem qualquer valor. Nesse engenho, assim como nas demais propriedades jesuíticas do Rio de Janeiro, esses bens não receberam nenhum tipo de avaliação financeira. Logo, imagina-se que não havia um interesse em colocá-los novamente no mercado. ${ }^{15}$

\footnotetext{
${ }^{14}$ Auto de inventário do engenho Velho. Arquivo Nacional Torre do Tombo.

${ }^{15}$ Auto de inventário do engenho Velho. Arquivo Nacional Torre do Tombo.
} 
O inventariante seguiu seu trabalho rumo a ferraria que ficava junto à casa de vivenda. Nela encontrou "um fole, uma safra e três martelos". Entretanto, de lá, avistou as 35 senzalas dos escravos e outras 32 que eram cobertas de palhas e também usadas pelos mesmos. ${ }^{16}$

Os desembargadores incumbidos de realizarem os inventários receberam ordens de inventariarem também o que encontrassem nas igrejas e nas sacristias, mas todos os objetos litúrgicos deveriam ficar nos mesmos locais e não deveriam ser avaliados, uma vez que segundo a concepção das autoridades, eles não pertenceriam aos jesuítas e sim, ao povo a e igreja como um todo. Depois de terminado o inventário, as portas das igrejas deveriam ser fechadas e a chave ficaria com uma pessoa responsável até a chegada de um padre capaz de assumir as atividades religiosas. Além das imagens, havia ainda dentro da igreja de São Francisco Xavier os demais objetos litúrgicos, tais como toalhas de missas, roupas dos padres, panos, cortinas, cálices, vasos, missais e etecetera. ${ }^{17}$

Durante o século XVIII, o que se percebe analisando as fazendas jesuíticas na capitania do Rio de Janeiro foi um grande crescimento econômico, uma consolidação de sua presença por praticamente todas as regiões, um aumento na produção agrícola e criatória e um constante incremento em sua população escrava. Além disso, a ordem já se havia voltado também para o acúmulo de inúmeros imóveis urbanos e os alugava aos moradores e comerciantes das cidades gerando uma significativa renda. Seus arrendamentos rurais e urbanos também eram outro ponto de sustentação dos colégios, que produziam e vendiam artigos, medicamentos, carnes e uma variedade de bens. Somado a tudo isso, a Companhia de Jesus era, nas Américas, controladora do trabalho da maior parte dos índios aldeados (Amantino, 2013, p. 123).

\section{CONCLUSÃO}

Durante 65 anos, ou seja, de 1565 a 1630, a Companhia de Jesus conseguiu controlar os seus principais elementos garantidores de poder na capitania do Rio de Janeiro: terras (aldeamentos, fazendas e engenhos) e pessoas (índios e negros). Atuaram como religiosos, mas acima de tudo, usaram seu poder junto aos indígenas para que os mesmos lutassem ao lado das autoridades metropolitanas. Os padres atuaram como elemento de destaque no processo de ocupação e consolidação do poder na capitania e também como intermediários entre culturas, facilitando os trânsitos,

${ }^{16}$ Auto de inventário do engenho Velho. Arquivo Nacional Torre do Tombo.

${ }^{17}$ Auto de inventário do engenho Velho. Arquivo Nacional Torre do Tombo. 
as trocas e lutando a favor de um projeto cristão, ainda que escravista. Como recompensas por todos os serviços prestados receberam inúmeras benesses, privilégios e honrarias. Na principal doação que receberam nas terras da recém fundada cidade, construíram seu colégio e anos depois, estabeleceram o engenho Velho.

Do sucesso econômico das suas propriedades dependia a continuidade da evangelização do Novo Mundo e para isto, suas estruturas agrárias precisavam ser autônomas e com o mínimo de dependência do mercado. A documentação utilizada permitiu acompanhar, no tempo, as principais atitudes dos jesuítas no tocante a sua inserção na economia da capitania e isto significou estar atento as oscilações que ocorriam no império como um todo. Ao perceberem a "guinada atlântica" do império, identificaram que era chegada a hora de investirem na produção do principal gênero do período: o açúcar. Esta produção somada à da Bahia e a de Pernambuco servia para o consumo interno, o abastecimento das cidades e para o envio para outros colégios da ordem em troca de variadas mercadorias. Suas propriedades agrárias na América portuguesa e na América espanhola foram sempre estabelecidas em pontos estratégicos: perto dos aldeamentos, nas principais rotas comercias e, quando possível, próximas a portos ou rios. Os principais objetivos destas escolhas eram manter a mão de obra indígena por perto em caso de necessidade de trabalhadores e ter rotas para escoar sua variada produção.

O engenho Velho era, evidentemente, uma unidade agrária produtiva, mas era também um microcosmos da sociedade colonial fluminense. No seu interior conviviam centenas de pessoas com qualidades e condições sócio jurídicas diferenciadas. Todos -mesmo os livres-deviam obediência ou pelo menos respeito aos padres inacianos, senhores da terra. Uns pagavam taxas e outros trabalhavam para eles, mas todos juntos davam a base de sustentação do poder econômico e político da Companhia de Jesus na cidade ao somarem seus esforços com os de outros de procedências diversas.

\section{LISTA DE REFERENCIAS}

Abreu, M. DE A. (2010). Geografia histórica do Rio de Janeiro, 1502-1700. Rio de Janeiro: Andrea Jakobsson Estúdio Editorial Ltda./Prefeitura do Município do Rio de Janeiro.

AcAdemia Brasileira de Letras (1936). Primeira publicação após 160 anos do manuscrito inédito de José Caeiro sobre os Jesuítas do Brasil e da Índia na perseguição do Marquês de Pombal (século XVIII). Bahia: Escola Tipográfica Salesiana.

Alden, D. (1996). The making of an enterprise: The Society ofJesus in Portugal, its empire and beyond 1540-1750. California: Stanford University Press. 
Alencastro, L. F. (2000). O trato dos viventes. São Paulo: Companhia das Letras.

Alveal, C. (2005). Enfiteuse. Em M. Motta (org.), Dicionário da terra. Rio de Janeiro: Civilização Brasileira.

Amantino, M. (2009). A expulsão dos jesuítas da Capitania do Rio de Janeiro e o confisco de seus bens. Revista do Instituto Histórico e Geográfico Brasileiro, 170(443), 169-192.

Amantino, M. (2013). Os jesuítas e seus escravos na capitania do Rio de Janeiro no século XVIII. Em E. Fernandes, A Companhia de Jesus na América. Rio de Janeiro:

Anchieta, J. DE (1984). Cartas. São Paulo: Loyola.

Assunção, P. DE (2004). Negócios jesuíticos: o cotidiano da administração dos bens divinos. São Paulo: Universidade de São Paulo.

Bernardes, L. M. C. (1995). Função defensiva do Rio de Janeiro e seu sítio original. Em L. M. Bernardes e M. T DE S. SoAREs, Rio de Janeiro: Cidade e região. Rio de Janeiro: Secretaria Municipal de Cultura.

Brasio, A. (1952). Monumenta missionária africana, África Ocidental (1469-1599) (vol. IV). Lisboa: Agência Geral do Ultramar.

Caetano, A. F. P. (2009). Entre drogas e cachaça: a política colonial e as tensões na América portuguesa (1640-1710). Alagoas: Universidade Federal de Alagoas.

Cavalcante, N. (2004). O Rio de Janeiro setecentista: a vida e a construção da cidade da invasão francesa até a chegada da Corte. Rio de Janeiro: Zahar.

Coaracy, V. (1965). O Rio de Janeiro do século XVII. Rio de Janeiro: José Olympio.

Enders, A. (2008). A história do Rio de Janeiro. Rio de Janeiro: Gryphus.

Engemann, C. e Amantino, M. (2013). Santa Cruz: de legado dos jesuítas a pérola da Coroa. Rio de Janeiro: Universidade do Estado do Rio,

Fragoso, J. L. (2007). Fidalgos e parentes de pretos; notas sobre a nobreza principal da terra do Rio de Janeiro (1600-1750). Em J. L. Fragoso, C. M. C. DE Almeida e A. C. J. DE SAmpaio (Orgs.) (2007). Conquistadores e negociantes: histórias de elites no Antigo Regime nos trópicos. América Lusa, séculos XVI a XVIII. Rio de Janeiro: Civilização Brasileira.

FranÇA, J. M. DE C. (2010). Informações sobre o Brasil Jesuíta: uma missiva do padre Luiz da Fonseca de 1576. Revista do Instituto Histórico e Geográfico Brasileiro, 171(446), pp. 251-288.

GRANDIN, G. (2004). O império da necessidade: escravatura, liberdade e ilusão no Novo Mundo. Rio de Janeiro: Rocco.

LeITe, S. (1940). Novas cartas jesuiticas (de Nobrega a Vieira). Rio de Janeiro: Companhia Editora Nacional.

LeITe, S. (1945). História da Companhia de Jesus no Brasil (vol. VI). Rio de Janeiro: Imprensa Nacional.

Livro de Tombo do Colégio de Jesus do Rio de Janeiro (1968). Em D. L. DE MACÊDO (Transcritor), Anais da Biblioteca Nacional (vol. 82). Rio de Janeiro: Biblioteca Nacional.

Mauro, F. (1997). Portugal, o Brasil e o Atlântico, 1570-1670. Lisboa: Estampa.

Mello, C. E. H. V. DE (1996). O Rio de Janeiro no Brasil quinhentista. São Paulo: Editorial Giordano. 
MEndonÇA, P. K. DE (1999). O Rio de Janeiro da pacificação: franceses e portugueses na disputa colonial. Rio de Janeiro: Secretaria Municipal de Cultura, Turismo e Esportes.

Neves, L. F. B. (1978). O combate dos soldados de Cristo na Terra dos Papagaios. Rio de Janeiro: Forense.

Ricupero, R. (2009). A formação da elite colonial: Brasil c. 1530-1630. São Paulo: Alameda.

SAMPAIO, A. C. J. DE (2003). Na encruzilhada do império: hierarquias sociais e conjunturas econômicas no Rio de Janeiro (c. 1650-c.1750). Rio de Janeiro: Arquivo Nacional.

SAmpaio, A. C. J. DE (2014). Fluxos e refluxos mercantis: centros, periferias e diversidade regionais. Em J. L. Fragoso e M. DE F. Gouvea, O Brasil colonial, 1580-1720 (vol. 2), Rio de Janeiro: Civilização Brasileira.

Santiago, C. C. A. O. (2015). As missões jesuíticas em Angola e suas ligações com a América Portuguesa de 1575 a 1592 (Dissertação do mestrado). Universidade Salgado de Oliveira, Niterói.

Schwartz, S. B. (2010). A economia do império português. Em F. Bethencourt e D. R. Curto (dirs.), A expansão marítima portuguesa, 1400-1800. Lisboa: Edicoes70.

Secreto, V. (2005). Arrendamento. Em M. Motta (org.). Dicionário da terra, Rio de Janeiro: Civilização Brasileira.

SoARes, F. (1966). Coisas notáveis do Brasil. Lisboa: Instituto Nacional do Livro/Ministério da Educação e Cultura.

Subrahmanyam, S. (2007). Holding the world in balance: The connected histories of the Iberian overseas empires, 1500-1640. The American Historical Review, 112(5), 1359-1385.

ZERon, C. A. DE M. R. (2011). Linha de fé: a Companhia de Jesus e a escravidão no processo de formação da sociedade colonial (Brasil, séculos XVI e XVII). São Paulo: Universidade de São Paulo.

\section{Bibliografia}

Amantino, M. (2011). Macaé nos séculos XVII e XVIII: ocupação e povoamento. Em M. Amantino, C. Rodrigues, C. Engemann, J. Freire, Povoamento, catolicismo e escravidão na Antiga Macaé (séculos XVII-XIX). Rio de Janeiro: Apicuri.

Amantino, M., Fleck, E., Deckmann, C., e Engemann, C. (2015). A Companhia de Jesus na América por seus colégios e fazendas: aproximações entre Brasil e Argentina, século XVIII. Rio de Janeiro: Garamond.

\section{Archivos}

Arquivo do Ministério da Fazenda, Rio de Janeiro, Brasil.

Arquivo Nacional Torre do Tombo, Lisboa, Portugal.

Arquivo Romano Societas Iesus, Roma, Itália. 